\title{
Evaluating the Sensitivities and Efficacies of Fungicides with Different Modes of Action Against Phomopsis asparagi
}

\author{
Niuniu Shi, Hongchun Ruan, Lin Gan, Yuli Dai, Xiujuan Yang, Yixin Du, ${ }^{\dagger}$ and Furu Chen ${ }^{\dagger}$ \\ Institute of Plant Protection, Fujian Academy of Agricultural Sciences, Fuzhou, Fujian, 350013, China, and Fujian Key Labora- \\ tory for Monitoring and Integrated Management of Crop Pests, Fuzhou, Fujian, 350013, China
}

\begin{abstract}
Asparagus stem blight caused by Phomopsis asparagi is a major hindrance to asparagus production worldwide. Currently, fungicides are used to manage the disease in commercial production, but resistance to common fungicides has emerged in the wild population. In the present study, 132 isolates of $P$. asparagi collected from different provinces in China were tested for sensitivities to pyraclostrobin, tebuconazole, and fluazinam. We also determined the efficacies of six fungicides against $P$. asparagi. The frequency distributions of $\mathrm{EC}_{50}$ values of the isolates tested were unimodal, but the curves for pyraclostrobin and tebuconazole had long right-hand tails. The mean $\mathrm{EC}_{50}$ values for pyraclostrobin, tebuconazole, and fluazinam were $0.0426 \pm 0.0029,0.6041 \pm 0.0416$, and $0.0314 \pm 0.0013 \mu \mathrm{g} / \mathrm{ml}$, respectively. In addition, the $\mathrm{EC}_{50}$ values for pyraclostrobin were very similar with or without salicylhydroxamic acid

fluxapyroxad plus pyraclostrobin SC), Frown-cide ( $500 \mathrm{~g} /$ liter fluazinam SC), Cabrio (250 g/liter pyraclostrobin EC), and Nativo (75\% trifloxystrobin plus tebuconazole WG) showed excellent preventive efficacy against $P$. asparagi. And these fungicides were more effective before inoculation than when they were applied after inoculation $(P<0.05)$. Therefore, these fungicides should be applied prior to infection to control stem blight. In field trials, Frown-cide, Merivon, Nativo, and Cabrio also performed good control effects, ranging from 75.2 to $86.0 \%$ in 2017 and 75.4 to $87.1 \%$ in 2018 . We demonstrated that Frown-cide, Merivon, Nativo, and Cabrio had considerable potential to manage asparagus stem blight. In addition, rotations of these fungicides are essential for precluding or delaying the development of resistance and for controlling the disease.
\end{abstract} (SHAM), $20 \mu \mathrm{g} / \mathrm{ml}$, indicating that SHAM is not needed to determine the sensitivity of $P$. asparagi to pyraclostrobin when using the mycelial growth inhibition assay. In greenhouse assays, Merivon $(42.4 \%$
Keywords: Phomopsis asparagi, control efficacy, diverse fungicides, baseline sensitivity, asparagus stem blight
Garden asparagus (Asparagus officinalis L.), known as the king of vegetables, is an economically important crop that has been cultivated for over 2,500 years. Asparagus has a high nutritional value with several health benefits including antioxidant, antiinflammatory, and antihepatotoxic properties (Almehdar et al. 2012; Dehghan-Shahreza et al. 2016; Li et al. 2016; Rusjan and Mikulic-Petkovsek 2017). This vegetable has become an essential item in cuisine (Yang et al. 2016). Over 50\% of the global cultivated asparagus area and volume occurs in China, which makes China currently the largest producer and exporter worldwide (Y. P. Zhang et al. 2012).

Stem blight disease caused by Phomopsis asparagi (Sacc.) Bubak has caused major setbacks in global asparagus production, particularly in humid areas (Davis 2001; Elena 2006). The disease has been reported in many Chinese provinces, including Fujian, Shandong, and Jiangxi (Meng et al. 2013). There are two highyielding seasons for asparagus in the subtropical regions of China, spring (from mid-April to early June) and autumn (from midAugust to mid-October). Outbreaks of stem blight occur in both seasons. The disease infects the leaves and the stem. Typical symptoms are round to oval lesions that are pale in color. Pycnidia are

${ }^{\dagger}$ Corresponding authors: Y. Du; yixindu@163.com, and F. Chen; chenfuruzb@163.com

Funding: This study was supported by the Special Fund for Agro-scientific Research in the Public Interest of Fujian province, China (2017R1025-5) and the Guidance Project of Fujian Academy of Agricultural Sciences (AC2017-16)

The author(s) declare no conflict of interest.

Accepted for publication 20 August 2019.

(C) 2020 The American Phytopathological Society usually observed within older lesions. As the disease progresses, plants desiccate completely and the stems die (Elena 2006).

None of the known asparagus varieties on the market are resistant to stem blight. The breeding of resistant varieties is difficult and timeconsuming because the species is dioecious and perennial (Sonoda et al. 1997). At present, fungicide application is still the primary method for managing stem blight disease. There are several fungicides registered against asparagus stem blight, such as difenoconazole, mancozeb, diniconazole, and thiophanate methyl, and so on (China Pesticide Information Network, http://www.icama.org.cn/fwb/ index.jhtml). In the past, the fungicides thiophanate methyl, carbendazol, and mancozeb were used widely in China to manage the disease. Resistance within P. asparagi to the three fungicides has been reported in China (Chen and Ye 1999; Meng et al. 2013). As the disease continues to spread geographically, new and effective fungicides are essential for $P$. asparagi management.

The strobilurin fungicides (quinine outside inhibitors, QoIs) are derived from natural products of wood-rotting fungi, including Oudemansiella mucida and Strobilurus tenacellus. The strobilurin fungicides inhibit mitochondrial respiration by blocking electron transfer within the respiratory chain (Bartlett et al. 2002), which in turn causes severe disruption of important cellular biochemical processes and stops fungal growth. However, when normal respiration is inhibited in the presence of QoIs, an alternative mitochondrial respiratory pathway can be activated (Kaneko and Ishii 2009), which is mediated by alternative oxidase (AOX) in fungi (Xu et al. 2012). This pathway may result in inaccuracies in vitro evaluations of QoI sensitivity. Therefore, AOX should be inhibited during in vitro assays. AOX is resistant to cyanide, but sensitive to salicylhydroxamic acid (SHAM) and $n$-propyl gallate ( $n$ PG) (Schonbaum et al. 1971). Pyraclostrobin is a broad spectrum foliar fungicide in the strobilurin chemical class, which has protective, curative, and eradicative activities against major plant pathogens (Stammler et al. 2012; Yang and Bai 2012), such as Ascochyta rabiei (Wise et al. 2008) and Fusarium spp. (Broders et al. 2007; Munkvold 2009). We define protective activity as the fungicide is applied before the pathogen arrives or infects 
the host and the fungicide protects the plant from infection. Curative activity occurs when the fungicide is applied after infection and prevents growth of the pathogen early in infection of the host tissues. Eradicative activity occurs when the fungicide is applied after symptoms develop (Ivic 2010). Unfortunately, owing to a single site of action and a high resistance risk (Bartlett et al. 2002), pyraclostrobin resistance has been reported in many plant fungal pathogens (Liang et al. 2015b; G. R. Zhang et al. 2012).

The triazole fungicides are part of the demethylation inhibitor fungicide group (DMIs) (Hamamoto et al. 2000), and contain several commercially successful compounds, such as difenoconazole and tebuconazole, which target the heme iron of cytochrome P450 sterol $14 \alpha$-demethylase (CYP51) and interfere with ergosterol biosynthesis of cell membrane of pathogen (Yoshida and Aoyama 1987). Tebuconazole is a triazole fungicide, which was developed in the late 1990s by the Bayer Corporation. It has been extensively used on a wide range of crops in many countries because of its ability to control diverse fungal diseases (He et al. 2018; Liang et al. 2018; Paul et al. 2007; Yoshimura et al. 2004). Furthermore, it is also one of the most important and widely used fungicides for disease control in rice within China (Liu et al. 2013; Wang et al. 2007). However, the extensive application of tebuconazole has provoked reduced sensitivity in many plant pathogens (Shi et al. 2017).

Fluazinam belongs to the novel broad-spectrum phenylpyridinamine fungicide that acts at all developmental stages from spore germination to sporulation, and especially infection. It is considered a protectant and has a good persistent effect and rain fastness, but has little curative or systemic activity (fungicide can be absorbed by plants and transported to other parts of plants) (Liang et al. 2015a). Fluazinam is very effective against a large number of plant pathogens (Lemay et al. 2002; Smith et al. 2008; Wang et al. 2016), but it is not effective against rusts and powdery mildew (Guan et al. 2014; Liu and Zhang 2017). To date, fluazinam has been registered in China to manage Phytophthora infestans in potato (Solanum tuberosum) and Plasmodiophora brassicae in Chinese cabbage (Brassica pekinensis) (Dowley and Sullivan 1995; Nielsen and Schepers 2014; Shi et al. 2016; Wang 2015).

Construction of baseline sensitivity is a significant part of the registration process for all fungicides in the European Union (Di et al. 2016), and baseline data are required by the Chinese registration authority (Fan et al. 2019). Pyraclostrobin, tebuconazole, and fluazinam have not yet been registered in China for the control of $P$. asparagi on asparagus (China Pesticide Information Network, http://www.icama.org.cn/fwb/index.jhtml). Thus, this is important to establish the baseline sensitivity of $P$. asparagi to these three fungicides and monitor fungicide resistance. Accordingly, we assessed the baseline sensitivities of $P$. asparagi to pyraclostrobin, tebuconazole, and fluazinam, determined the efficacies of six fungicides [Cabrio ( $250 \mathrm{~g} /$ liter pyraclostrobin EC), Frown-cide ( $500 \mathrm{~g} /$ liter fluazinam SC), Folicur (430 g/liter tebuconazole SC), Dithane M-45 (80\% mancozeb WP), Nativo (75\% trifloxystrobin plus tebuconazole WG), and Merivon (42.4\% fluxapyroxad plus pyraclostrobin SC)] against $P$. asparagi in a greenhouse and in the field.

\section{Materials and Methods}

Experimental material: $P$. asparagi isolates and asparagus cultivar. We collected 132 fungal isolates from two to three fields of naturally infected asparagus in each of seven Chinese provinces: Fujian, Shandong, Henan, Hunan, Shanxi, Jiangxi, and Zhejiang (Table 1). The sampled fields were separated by at least $100 \mathrm{~km}$ from one another. Twenty young stems from plants with typical symptoms were collected at random within each field. Symptomatic tissues were cut into $3-5 \mathrm{~mm}$ pieces, and surface-sterilized by immersion in $75 \%(\mathrm{vol} / \mathrm{vol})$ ethanol for $30 \mathrm{~s}$, followed by $1 \% \mathrm{NaClO}$ for $1.5 \mathrm{~min}$, then rinsed three times in distilled water, and incubated on potato dextrose agar (PDA) at $28^{\circ} \mathrm{C}$. After $3-5$ days, mycelia were transferred to fresh PDA plates at $28^{\circ} \mathrm{C}$ for $2-3$ weeks to encourage pycnidial formation. Then single conidium isolations were made as described earlier (Meng 2013). All isolates were identified on the basis of morphology and partial sequence analysis of ITS, and preserved on filter paper and stored at $-20^{\circ} \mathrm{C}$.

The cultivar, 'Grande F1', which is susceptible to asparagus stem blight, was used to assess fungicide efficacy in greenhouse and field trials.

Fungicides. Technical grade products of each fungicide were used in the fungicide sensitivity assays. Pyraclostrobin (98\% active ingredient [a.i.]; Jiangsu Huifeng Agrochemical Co., Ltd., Dafeng, China), tebuconazole (95\% a.i.; Nantong Taihe Chemical Co., Ltd., Nantong, China), and fluazinam (97\% a.i.; Ishihara Sangyo Kaisha, Osaka, Japan) were dissolved in dimethyl sulfoxide (DMSO) to produce stock solutions of $10,000 \mu \mathrm{g} / \mathrm{ml}$. Salicylhydroxamic acid (SHAM, 99\% a.i.; Sigma-Aldrich, St. Louis, MO, USA) was dissolved in DMSO to obtain a $9.6 \times 10^{4} \mu \mathrm{g} / \mathrm{ml}$ stock solution. The stock solutions were stored in a refrigerator at $4{ }^{\circ} \mathrm{C}$ for no longer than 2 weeks before being serially diluted for fungicide sensitivity trials.

Commercially formulated fungicides containing Cabrio (250 g/liter pyraclostrobin EC, BASF China Ltd., Shanghai, China), Frown-cide (500 g/liter fluazinam SC, Japan Ishihara Sangyo Kaisha), Folicur (430 g/liter tebuconazole SC, Bayer Crop Science [China] Co., Ltd., Hangzhou, China), Dithane M-45 (80\% mancozeb WP, Dow Agrosciences China Ltd., Nantong, China), Nativo (75\% trifloxystrobin plus tebuconazole WG, Bayer Crop Science [China] Co., Ltd.), and Merivon (42.4\% fluxapyroxad plus pyraclostrobin SC, BASF China Ltd., Shanghai, China) were dissolved in water.

Determination of $\mathbf{E C}_{50}$ values and baseline sensitivities of $P$. asparagi to pyraclostrobin, tebuconazole, and fluazinam. We determined $\mathrm{EC}_{50}$ values of fungicides using a mycelial growth inhibition assay based on the procedures described in Amiri et al. (2013), with minor modifications. Potato dextrose agar (PDA) was serially amended with pyraclostrobin to give final concentrations

Table 1. Sensitivities of Phomopsis asparagi isolates to pyraclostrobin, tebuconazole, and fluazinam in China

\begin{tabular}{|c|c|c|c|c|c|c|c|}
\hline \multirow[b]{2}{*}{ Location } & \multirow{2}{*}{$\begin{array}{c}\text { Number of } \\
\text { isolates }\end{array}$} & \multicolumn{2}{|c|}{ EC $_{50}$ for Pyraclostrobin $(\mu \mathrm{g} / \mathrm{ml})^{x}$} & \multicolumn{2}{|c|}{$\mathrm{EC}_{50}$ for Tebuconazole $(\mu \mathrm{g} / \mathrm{ml})$} & \multicolumn{2}{|c|}{$\mathrm{EC}_{50}$ for Fluazinam $(\boldsymbol{\mu g} / \mathrm{ml})$} \\
\hline & & Range & Mean $^{y}$ & Range & Mean & Range & Mean \\
\hline Fujian & 23 & $0.0134-0.1532$ & $0.0468 \pm 0.0071 \mathrm{a}$ & $0.0821-2.5227$ & $0.8664 \pm 0.1440 \mathrm{a}$ & $0.0107-0.0620$ & $0.0322 \pm 0.0028 \mathrm{a}$ \\
\hline Henan & 20 & $0.0125-0.1238$ & $0.0506 \pm 0.0099 a$ & $0.0752-1.8736$ & $0.6513 \pm 0.1078 a$ & $0.0081-0.0579$ & $0.0316 \pm 0.0032 \mathrm{a}$ \\
\hline Hunan & 18 & $0.0108-0.0920$ & $0.0341 \pm 0.0049 \mathrm{a}$ & $0.0207-1.0621$ & $0.4530 \pm 0.0717 \mathrm{a}$ & $0.0048-0.0526$ & $0.0329 \pm 0.0042 \mathrm{a}$ \\
\hline Jiangxi & 18 & $0.0107-0.1506$ & $0.0449 \pm 0.0095 \mathrm{a}$ & $0.0275-1.6178$ & $0.5452 \pm 0.0958 \mathrm{a}$ & $0.0067-0.0549$ & $0.0299 \pm 0.0035 \mathrm{a}$ \\
\hline Sanxi & 19 & $0.0111-0.1511$ & $0.0474 \pm 0.0083 a$ & $0.1098-2.1180$ & $0.6273 \pm 0.1126 a$ & $0.0115-0.0533$ & $0.0320 \pm 0.0029 a$ \\
\hline Shandong & 17 & $0.0120-0.1006$ & $0.0357 \pm 0.0050 \mathrm{a}$ & $0.0542-1.3406$ & $0.4998 \pm 0.0839 \mathrm{a}$ & $0.0068-0.0628$ & $0.0295 \pm 0.0038 \mathrm{a}$ \\
\hline Zhejiang & 17 & $0.0098-0.1305$ & $0.0359 \pm 0.0070 \mathrm{a}$ & $0.0663-1.2314$ & $0.4941 \pm 0.0819 \mathrm{a}$ & $0.0058-0.0615$ & $0.0312 \pm 0.0041 \mathrm{a}$ \\
\hline Total & 132 & $0.0098-0.1532$ & $0.0426 \pm 0.0029$ & $0.0207-2.5227$ & $0.6041 \pm 0.0416$ & $0.0048-0.0628$ & $0.0314 \pm 0.0013$ \\
\hline$V F^{z}$ & & 15.63 & & 121.87 & & 13.08 & \\
\hline
\end{tabular}

\footnotetext{
${ }^{\mathrm{x}} \mathrm{EC}_{50}$, the effective concentration of the fungicide causing $50 \%$ inhibition of mycelial growth on PDA media.

${ }^{y}$ Mean \pm SEM (standard error of the mean), different lowercase letters identify significantly different means in columns (Tukey's multiple comparisons test; $P=0.05)$
}

${ }^{\mathrm{z}} V F=\left(\right.$ Maximum $\left.\mathrm{EC}_{50}\right) /\left(\right.$ Minimum $\left.\mathrm{EC}_{50}\right)$ 
of $0.00625,0.0125,0.025,0.05,0.1$, and $0.5 \mu \mathrm{g}$ a.i./ml. Similarly, PDA was amended with tebuconazole at final concentrations of $0.02,0.04,0.2,1,5$, and $20 \mu \mathrm{g}$ a.i./ml, or fluazinam at final concentrations of $0.00625,0.0125,0.025,0.05$, and $0.1 \mu \mathrm{g}$ a.i. $/ \mathrm{ml}$. PDA plates amended with $0.1 \%$ ( $\mathrm{vol} / \mathrm{vol}$ ) DMSO served as control. A 5-mm mycelial plug of each $P$. asparagi isolate was cut from the periphery of a 5-day-old colony growing on PDA and placed upside down onto the center of fungicide-amended PDA plates. After $7-9$ days of incubation at $28^{\circ} \mathrm{C}$ in the dark, we measured the colony diameter of each isolate twice at right angle coordinate positions. Each fungicide concentration had five replicates and the experiments were conducted twice.

Effect of SHAM on mycelial growth of $P$. asparagi. A stock solution of SHAM was diluted and added to PDA media to obtain final concentrations of $10,20,40,80,160$, and $320 \mu \mathrm{g} / \mathrm{ml}$, respectively. PDA amended with $0.1 \%$ (vol/vol) DMSO served as a control. Ten isolates that differed in $\mathrm{EC}_{50}$ values to pyraclostrobin were selected and tested for the toxic effects of SHAM on mycelial growth. Isolates were prepared for plating using the methods described above. The experiments were performed three times.

The $\mathrm{EC}_{50}$ values of pyraclostrobin in the presence of SHAM (at a concentration of $20 \mu \mathrm{g} / \mathrm{ml}$ ) were also assessed on pyraclostrobinamended PDA. Control plates were prepared with DMSO only.

Preventive and curative efficacies of six fungicides against $\boldsymbol{P}$. asparagi in a greenhouse. Ten isolates from seven provinces were used in this study (Table 2). The 10 isolates were incubated at $28^{\circ} \mathrm{C}$ on PDA plates for $2-3$ weeks to encourage pycnidial formation. Ten to $15 \mathrm{ml}$ of distilled water were added to the plates and the surface of the colonies was gently washed with a paintbrush. The conidial suspension of a mixture of 10 isolates was filtered through two layers of cheesecloth and adjusted to $1 \times 10^{5}$ conidia/ml with $0.1 \%$ aqueous solution Tween 80 surfactant. Asparagus seeds were soaked in hot water $\left(55-58^{\circ} \mathrm{C}\right)$ for $20 \mathrm{~min}$, rinsed in cold water, and then immersed in 50\% carbendazim WP at $500 \mu \mathrm{g}$ a.i./ml for $48 \mathrm{~h}$. The seeds were subsequently germinated for $72 \mathrm{~h}$ at $28^{\circ} \mathrm{C}$ and $100 \%$ humidity, then one seed was sown in a polypropylene pot containing sphagnum peat soil (Pindstrup, Ryomgaard, Denmark). The plants were incubated at $24-28^{\circ} \mathrm{C}$ in a greenhouse $(12 \mathrm{~h}$ light and $\mathrm{RH}>90 \%)$. To determine the efficacy of a preventative application of a fungicide, seedlings were first sprayed with dilutions of Cabrio at rates of 84.38, 112.5, and $168.75 \mathrm{~g}$ a.i./ha, Frown-cide at 187.50, 225.00, and $262.50 \mathrm{~g}$ a.i./ha, Folicur at $64.50,96.75$, and $129.00 \mathrm{~g}$ a.i./ha, Dithane M-45 at $1350.00,1800.00$, and $2700.00 \mathrm{~g}$ a.i./ha, Nativo at $33.75+67.50,42.19+84.38$, and $56.25+112.50 \mathrm{~g}$ a.i./ha, and Merivon at 57.24 + 57.24, $71.55+71.55$, and $95.40+95.40 \mathrm{~g}$ a.i./ha, respectively, using a knapsack sprayer (Matabi super green16). Then the plants were inoculated with a conidial suspension $(1 \times$ $10^{5}$ conidia $/ \mathrm{ml}$ ) described above $24 \mathrm{~h}$ after fungicide application. To determine the efficacy of a curative application on a fungicide, a conidial suspension $\left(1 \times 10^{5}\right.$ conidia/ml $)$ was first sprayed on the asparagus seedlings, then fungicide treatments were applied to the seedlings $24 \mathrm{~h}$ after inoculation. Control plants were sprayed with a $0.1 \%$ Tween 80 solution. The treated plants and control plants were maintained under greenhouse conditions as described above. Each dose of each fungicide contained 20 plants, each of which had three replicates. All experiments were conducted in triplicate.

Disease severity was evaluated on a 0-9 scale according to the evaluation system of Yang et al. (2012) with slight modifications, where: 0 , no evidence of infection; $1, \leq 5 \%$ of the stem surface diseased; 3,5 to $15 \%$ of the stem surface diseased; 5,16 to $25 \%$ of the stem surface diseased; 7,26 to $50 \%$ of the stem surface diseased; 9 , $\geq 50 \%$ of the stem surface diseased. The disease index and control efficacy for each fungicide were calculated according to the following formulas (Dai et al. 2018).

Disease index
$=\frac{\sum(\text { the number of diseased plants in this scale } \times \text { the disease scale })}{\text { the total plants investigated } \times 9} \times 100$

Control efficacy $(\%)$ $=\frac{\text { disease index of control }- \text { disease index of treated }}{\text { disease index of control }} \times 100$

Control efficacies of six fungicides against asparagus stem blight in field trials. A field with a history of stem blight, located in Zhuangbian Town, Hanjiang District, Putian, Fujian Province, China, was used for this experiment. Trials were performed on 3year-old plants of the asparagus hybrid cv. 'Grande F1' in 2017 and 2018. Plants were spaced at $25-\mathrm{cm}$ intervals and the row spacing was $1.5 \mathrm{~m}$. Per plot consisted of $30 \mathrm{~m}^{2}$ ( $3 \mathrm{~m}$ wide $\times 10 \mathrm{~m}$ long). The trial contained 19 treatments in a randomized block design with three replications. The same fungicides and rates used in a greenhouse were applied until runoff to the plants in the field using knapsack sprayer (Matabi super green16). Control plants were sprayed with water. In 2017, fungicides were first applied on 5 September 2017, with subsequent applications at 7-day intervals for 2 weeks; in 2018, fungicides were first applied on 28 April 2018, with subsequent applications at 7-day intervals for 2 weeks. Disease severity was measured 14 days after the last application. The disease index and control efficacy were calculated as described above.

Statistical analyses. The fungicide concentrations and corresponding inhibitions were used to calculate $\mathrm{EC}_{50}$ values with the Bioassay Analysis for Quantitative Data in Data Processing System software (ver. 7.05; Hangzhou RuiFeng Information Technology Co. Ltd., Hangzhou, China). Baseline sensitivity was calculated from

Table 2. $\mathrm{EC}_{50}$ values for 10 Phomopsis asparagi isolates on pyraclostrobin-amended PDA with and without SHAM

\begin{tabular}{|c|c|c|c|c|c|c|}
\hline \multirow[b]{2}{*}{ Isolate } & \multirow[b]{2}{*}{ Location } & \multicolumn{2}{|c|}{ Pyraclostrobin with SHAM" } & \multicolumn{2}{|c|}{ Pyraclostrobin without SHAM } & \multirow[b]{2}{*}{ Significance $^{\mathrm{y}}$} \\
\hline & & $\mathrm{EC}_{50}(\mu \mathrm{g} / \mathrm{ml})$ & $95 \%$ CI of $\mathrm{EC}_{50} \mathrm{x}$ & $\mathrm{EC}_{50}(\mu \mathrm{g} / \mathrm{ml})$ & $95 \% \mathrm{CI}$ of $\mathrm{EC}_{50}$ & \\
\hline $\mathrm{sd} 34$ & Shandong & 0.0179 & $0.0097-0.0331$ & 0.0221 & $0.0130-0.0378$ & $\ldots$ \\
\hline zb15 & Fujian & 0.0297 & $0.0237-0.0371$ & 0.0534 & $0.0387-0.0742$ & $*$ \\
\hline hn30 & Hunan & 0.0145 & $0.0056-0.0377$ & 0.0148 & $0.0061-0.0362$ & $\ldots$ \\
\hline qd53 & Jiangxi & 0.0392 & $0.0214-0.0717$ & 0.0421 & $0.0219-0.0806$ & $\ldots$ \\
\hline zj28 & Zhejiang & 0.0370 & $0.0304-0.0450$ & 0.0357 & $0.0281-0.0476$ & $\ldots$ \\
\hline $\mathrm{hn} 34$ & Henan & 0.0130 & $0.0070-0.0242$ & 0.0151 & $0.0110-0.0208$ & $\ldots$ \\
\hline sx37 & Sanxi & 0.0112 & $0.0054-0.0233$ & 0.0229 & $0.0178-0.0294$ & $\ldots$ \\
\hline $\operatorname{sd} 20$ & Shandong & 0.0194 & $0.0081-0.0463$ & 0.0233 & $0.0165-0.0329$ & $\ldots$ \\
\hline zb07 & Fujian & 0.0092 & $0.0058-0.0148$ & 0.0108 & $0.0079-0.0148$ & $\ldots$ \\
\hline $\mathrm{j} \times 43$ & Jiangxi & 0.0133 & $0.0082-0.0215$ & 0.0152 & $0.0081-0.0288$ & $\ldots$ \\
\hline Average & & 0.0204 & & 0.0255 & & $P=0.057^{\mathrm{z}}$ \\
\hline
\end{tabular}

${ }^{w}$ Final concentration of SHAM in PDA media was $20 \mu \mathrm{g} / \mathrm{ml}$.

$x$ The 95\% confidence intervals (CIs) were calculated using Data Processing System software (ver. 7.05; Hangzhou RuiFeng Information Technology Co. Ltd.).

$\mathrm{y} *$ denotes that there was not significant difference in $\mathrm{EC}_{50}$ values between pyraclostrobin with and without SHAM.

z Student's paired $t$ test was employed for significant difference in the mean $\mathrm{EC}_{50}$ values of the 10 isolates between pyraclostrobin with and without $\mathrm{SHAM}$. 
the frequency distributions of $\mathrm{EC}_{50}$ values for the 132 isolates following the procedures of Russell (2004). Pairwise significant differences in mean $\mathrm{EC}_{50}$ values between different $P$. asparagi populations were identified using Tukey's multiple comparisons test in one way analysis of variance (ANOVA). Student's paired $t$ test was employed for significant difference in the mean $\mathrm{EC}_{50}$ values between pyraclostrobin with and without SHAM, and between preventive and curative efficacies. Preventive and curative efficacies in a greenhouse, and control efficacies in a field were subjected to ANOVA using Duncan's new multiple-range test (DMRT) $(P \leq$ $0.05)$. All data were arcsine square-root transformed prior to statistical analyses (McDonald 2009).

\section{Results}

Baseline sensitivity of $P$. asparagi to pyraclostrobin, tebuconazole, and fluazinam. The $\mathrm{EC}_{50}$ values of $132 \mathrm{P}$. asparagi isolates collected from different provinces of China for pyraclostrobin, tebuconazole, and fluazinam ranged from $0.0098-0.1532 \mu \mathrm{g} / \mathrm{ml}$, $0.0207-2.5227 \mu \mathrm{g} / \mathrm{ml}$, and $0.0048-0.0628 \mu \mathrm{g} / \mathrm{ml}$, respectively, and the respective mean $\mathrm{EC}_{50}$ values were $0.0426 \pm 0.0029 \mu \mathrm{g} / \mathrm{ml}$, $0.6041 \pm 0.0416 \mu \mathrm{g} / \mathrm{ml}$, and $0.0314 \pm 0.0013 \mu \mathrm{g} / \mathrm{ml}$ (Table 1). The $\mathrm{EC}_{50}$ ranges for pyraclostrobin and fluazinam were narrow, while a broader range of sensitivity values was detected for tebuconazole with the variation factor $\left[V F\right.$, (maximum $\mathrm{EC}_{50}$ ) / (minimum $\left.\mathrm{EC}_{50}\right)$ ] of 121.87 (Table 1). There was no significant difference $(P=0.6207,0.9938,0.085$, respectively) in sensitivities (mean $\mathrm{EC}_{50}$ values) among the seven populations for pyraclostrobin, fluazinam, and tebuconazole (Table 1).

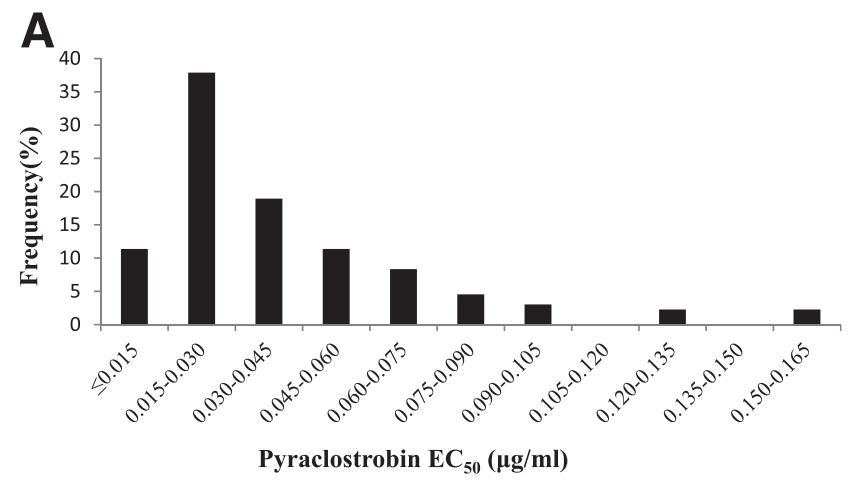

B
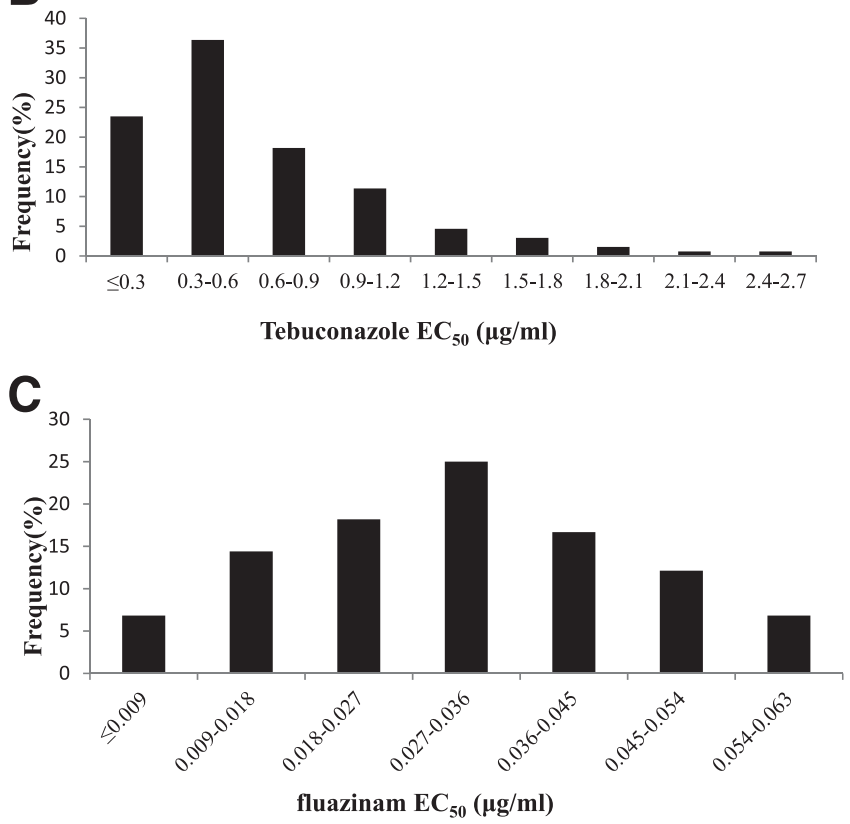

Fig. 1. Frequency distributions of sensitivity values $\left(E C_{50}\right)$ for 132 isolates of Phomopsis asparagi to pyraclostrobin (A), tebuconazole (B), and fluazinam (C).
The frequency distributions of sensitivities to pyraclostrobin and tebuconazole were similar in shape, unimodal with a long righthand tail (Fig. 1A and B). The frequency distribution of sensitivities to fluazinam fit a normal curve $(P=0.8517$, Kolmogorov-Smirnov goodness-of-fit test) (Fig. 1C).

Toxic effects of SHAM on the mycelial growth of $\boldsymbol{P}$. asparagi. Mycelia of the four isolates (zb30, hn34, sx37, and sd20) growing on PDA plates had a quantitative dose response to SHAM, with $\mathrm{EC}_{50}$ values of $306.75,117.54,118.16$, and $132.05 \mu \mathrm{g} / \mathrm{ml}$, respectively (Fig. 2). All isolates grew well at a SHAM concentration of $10 \mu \mathrm{g} / \mathrm{ml}$, but significant growth inhibition occurred at concentrations $\geq 40 \mu \mathrm{g} / \mathrm{ml}$. The results demonstrated that SHAM at concentrations $\leq 20 \mu \mathrm{g} / \mathrm{ml}$ had inapparent toxic effects on the mycelial growth of $P$. asparagi.

Effects of SHAM on mycelial growth of $P$. asparagi on PDA. In pyraclostrobin-amended PDA, the $\mathrm{EC}_{50}$ values of the 10 isolates tested were similar with and without SHAM $(20 \mu \mathrm{g} / \mathrm{ml})$ (Table 2). The average $\mathrm{EC}_{50}$ value across the 10 isolates was $0.0255 \mu \mathrm{g} / \mathrm{ml}$ for pyraclostrobin without SHAM, and $0.0204 \mu \mathrm{g} / \mathrm{ml}$ with SHAM. Mean $\mathrm{EC}_{50}$ values between pyraclostrobin with and without SHAM were not significantly different $(P=0.057)$ according to a paired $t$ test.

Preventive and curative efficacies of six fungicides against $\boldsymbol{P}$. asparagi in a greenhouse. Merivon, Frown-cide, Cabrio, and Nativo showed excellent preventive efficacy against $P$. asparagi (Table 3 ). The highest concentration of Merivon $(95.40+95.40 \mathrm{~g}$ a.i./ha), Frown-cide (262.50 g a.i./ha), Cabrio (168.75 g a.i./ha), and Nativo $(56.25+112.50 \mathrm{~g}$ a.i./ha) reduced disease severity by $87.9,87.3$, 86.7 , and $85.5 \%$, respectively, $24 \mathrm{~h}$ prior to inoculation, and there was significant difference $(P<0.05)$ with the efficacy of Dithane M-45 at a rate of $2700.00 \mathrm{~g}$ a.i./ha, which was $74.7 \%$. Compared with the preventive activities, the curative activities of all fungicides tested were lower at the same concentrations according to Student's paired $t$ test $(P<0.05)$.

Control efficacies of six fungicides against asparagus stem blight in field trials. Disease index in the untreated controls was $19.7 \%$ in 2017 and $31.0 \%$ in 2018 (Table 4). The disease severity values in all treatments were significantly lower than those in the untreated controls $(P<0.05)$. Among six fungicides, Frown-cide and Merivon exhibited better control efficacy at 262.50 and $95.40+$ $95.40 \mathrm{~g}$ a.i./ha compared with other fungicides at the highest dose during 2 years, and reduced disease severity by 86.0 and $85.3 \%$ in 2017 , and 87.1 and $86.1 \%$ in 2018 , respectively. Cabrio at a rate of $168.75 \mathrm{~g}$ a.i./ha was not significantly different $(P>0.05)$ from the efficacy of Nativo at $56.25+112.50 \mathrm{~g}$ a.i./ha during 2 years. The control efficacy of Dithane M-45 at $2700.00 \mathrm{~g}$ a.i./ha was significantly different $(P<0.05)$ from that of five other fungicides tested at the highest dose. In general, the efficacies of fungicides tested were

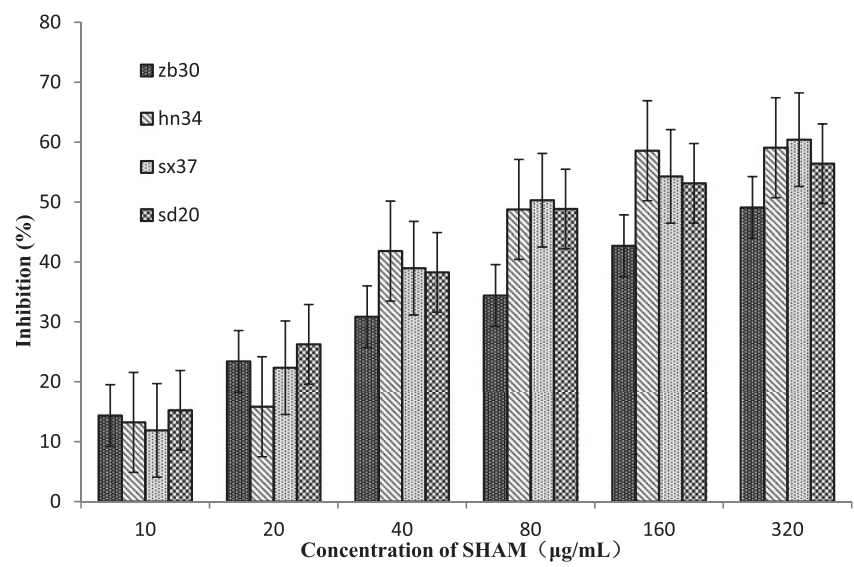

Fig. 2. Mycelial growth inhibitions of Phomopsis asparagi by increasing concentrations of salicylhydroxamic acid (SHAM) on PDA media. The error bar indicates standard deviation (SD) of four replicates. 
relatively stable during the two consecutive years, ranging from 67.8 to $86.0 \%$ in 2017 and 68.7 to $87.1 \%$ in 2018 .

\section{Discussion}

Establishment of baseline sensitivities and corresponding discriminatory doses are crucial, especially in the light of fungicide resistance development. In the current study, 132 isolates of $P$. asparagi collected from seven provinces of China were tested for sensitivities to three fungicides that have yet to be registered for use on asparagus in China. Technically, baseline sensitivity should be established by testing a target pathogen without an exposure history (Russell 2004). The sensitivity data obtained in our study cannot be considered as definitive baselines but rather relative baselines because it is not clear whether the isolates tested had been previously exposed to other fungicides with the same mechanism.
Nevertheless, these relative baseline sensitivities will be valuable for monitoring resistance levels in $P$. asparagi populations in China in the future (Russell 2002). Most of the isolates tested were sensitive to the three fungicides, and the frequency distribution of each fungicide was unimodal. Moreover, the sensitivity frequency distributions of pyraclostrobin and tebuconazole had long right-hand tails on the sensitivity distribution curve. A long right-hand tail on a sensitivity distribution curve may indicate a strong potential for future resistance. In fact, resistance development for strobilurins (QoI fungicides) and triazoles (DMI fungicides) has been reported in many pathogens (Ahmed et al. 2014; Banno et al. 2009; Milgate et al. 2016). Although Fungicide Resistance Action Committee (FRAC) has listed fluazinam as a low-risk fungicide, resistance to fluazinam has been reported in Ustilago maydis (FRAC 2014; Vitoratos 2014). Therefore, monitoring P. asparagi populations

Table 3. Preventive and curative activities of six fungicides against asparagus stem blight in a greenhouse

\begin{tabular}{|c|c|c|c|c|c|}
\hline Fungicides & Active ingredients & Chemical group & $\begin{array}{c}\text { Product rate } \\
(\text { a.i. g ha-1) }\end{array}$ & $\begin{array}{c}\text { Preventive efficacy } \\
(\%)^{\mathbf{x}}\end{array}$ & $\begin{array}{c}\text { Curative efficacy } \\
(\%)^{\mathrm{y}}\end{array}$ \\
\hline \multirow[t]{3}{*}{ Cabrio } & Pyraclostrobin & Strobilurin & 84.38 & $79.2 \operatorname{defg}^{\mathrm{z}}$ & $72.2 \mathrm{fgh}$ \\
\hline & & & 112.50 & 81.7 cde & 75.2 cdef \\
\hline & & & 168.75 & $86.7 \mathrm{ab}$ & 77.2 bcde \\
\hline \multirow[t]{3}{*}{ Frown cide } & Fluazinam & Pyridines & 187.50 & 81.7 cde & $73.2 \mathrm{efgh}$ \\
\hline & & & 225.00 & $83.6 \mathrm{abcd}$ & 76.5 cde \\
\hline & & & 262.50 & $87.3 \mathrm{a}$ & $80.8 \mathrm{ab}$ \\
\hline \multirow[t]{3}{*}{ Folicur } & Tebuconazole & Triazole & 64.50 & $75.4 \mathrm{fgh}$ & $70.3 \mathrm{gh}$ \\
\hline & & & 96.75 & 77.7 efg & 74.0 defg \\
\hline & & & 129.00 & $79.8 \mathrm{def}$ & $78.5 \mathrm{abc}$ \\
\hline \multirow[t]{3}{*}{ Dithane M-45 } & Mancozeb & Organosulfur & 1350.00 & $69.4 \mathrm{i}$ & $62.2 \mathrm{j}$ \\
\hline & & & 1800.00 & $72.2 \mathrm{hi}$ & $65.9 \mathrm{ij}$ \\
\hline & & & 2700.00 & $74.7 \mathrm{gh}$ & $69.3 \mathrm{hi}$ \\
\hline \multirow[t]{3}{*}{ Nativo } & Trifloxystrobin+Tebuconazole & Strobilurin+Triazole & $33.75+67.50$ & $78.5 \mathrm{efg}$ & $70.1 \mathrm{gh}$ \\
\hline & & & $42.19+84.38$ & 82.2 bcde & 73.3 efgh \\
\hline & & & $56.25+112.50$ & $85.5 \mathrm{abc}$ & 77.1 bcde \\
\hline \multirow[t]{3}{*}{ Merivon } & Pyraclostrobin+Fluxapyroxad & Strobilurin+SDHI & $57.24+57.24$ & 81.5 cde & 73.7 efg \\
\hline & & & $71.55+71.55$ & $84.8 \mathrm{abc}$ & $78.1 \mathrm{bcd}$ \\
\hline & & & $95.40+95.40$ & $87.9 \mathrm{a}$ & $82.2 \mathrm{a}$ \\
\hline
\end{tabular}

${ }^{\mathrm{x}}$ Fungicides for preventive efficacy were applied $24 \mathrm{~h}$ before inoculation.

y Fungicides for curative efficacy were applied $24 \mathrm{~h}$ after inoculation.

${ }^{z}$ Mean \pm SEM (standard error of the mean); values in the same column followed by different lowercase letters are significantly different according to Duncan's new multiple-range test $(P \leq 0.05)$.

Table 4. Control efficacies of six fungicides against asparagus stem blight in 2017 and 2018 field trials

\begin{tabular}{|c|c|c|c|c|c|c|c|}
\hline \multirow[b]{2}{*}{ Treatment } & \multirow[b]{2}{*}{ Active ingredients } & \multirow[b]{2}{*}{ Chemical group } & \multirow{2}{*}{$\begin{array}{l}\text { Product rate } \\
(\text { a.i. g ha } \\
-1 \text { ) }\end{array}$} & \multicolumn{2}{|c|}{ Disease index } & \multicolumn{2}{|c|}{$\begin{array}{c}\text { Control efficacy } \\
(\%)^{y}\end{array}$} \\
\hline & & & & 2017 & 2018 & 2017 & 2018 \\
\hline \multirow{4}{*}{$\begin{array}{l}\text { Non-treated control } \\
\text { Cabrio }\end{array}$} & & & & $19.7 \mathrm{a}$ & $31.0 \mathrm{a}$ & & \\
\hline & Pyraclostrobin & Strobilurin & 84.38 & $4.9 \mathrm{~cd}$ & $6.9 \mathrm{def}$ & $75.2 \mathrm{ij}^{\mathrm{z}}$ & 77.8 efg \\
\hline & & & 112.50 & $3.9 \mathrm{efg}$ & $6.1 \mathrm{fgh}$ & $80.0 \mathrm{ef}$ & $80.3 \mathrm{de}$ \\
\hline & & & 168.75 & $3.3 \mathrm{hij}$ & $5.3 \mathrm{ghi}$ & $83.5 \mathrm{c}$ & $82.9 \mathrm{bc}$ \\
\hline \multirow[t]{3}{*}{ Frown cide } & Fluazinam & Pyridines & 187.50 & $4.2 \mathrm{ef}$ & $6.2 \mathrm{efg}$ & $78.8 \mathrm{fg}$ & $80.0 \mathrm{de}$ \\
\hline & & & 225.00 & $3.5 \mathrm{ghi}$ & $4.7 \mathrm{hi}$ & $82.1 \mathrm{~cd}$ & $84.8 \mathrm{ab}$ \\
\hline & & & 262.50 & $2.8 \mathrm{j}$ & $4.0 \mathrm{i}$ & $86.0 \mathrm{a}$ & $87.1 \mathrm{a}$ \\
\hline \multirow[t]{3}{*}{ Folicur } & Tebuconazole & Triazole & 64.50 & $5.0 \mathrm{~cd}$ & $7.6 \mathrm{cde}$ & $74.6 \mathrm{jk}$ & $75.3 \mathrm{gh}$ \\
\hline & & & 96.75 & $4.5 \mathrm{de}$ & $7.1 \mathrm{def}$ & $77.1 \mathrm{gh}$ & $77.0 \mathrm{fgh}$ \\
\hline & & & 129.00 & $4.1 \mathrm{efg}$ & $6.0 \mathrm{fgh}$ & $79.3 \mathrm{ef}$ & $80.6 \mathrm{~cd}$ \\
\hline \multirow[t]{3}{*}{ Dithane M-45 } & Mancozeb & Organosulfur & $1,350.00$ & $6.3 \mathrm{~b}$ & $9.7 \mathrm{~b}$ & $67.8 \mathrm{~m}$ & $68.7 \mathrm{j}$ \\
\hline & & & $1,800.00$ & $5.9 \mathrm{~b}$ & $8.8 \mathrm{bc}$ & 70.01 & $71.7 \mathrm{i}$ \\
\hline & & & $2,700.00$ & $5.2 \mathrm{c}$ & $8.0 \mathrm{~cd}$ & $73.3 \mathrm{k}$ & $74.5 \mathrm{~h}$ \\
\hline \multirow[t]{3}{*}{ Nativo } & Trifloxystrobin+Tebuconazole & Strobilurin+Triazole & $33.75+67.50$ & $4.5 \mathrm{de}$ & 7.6 cde & $76.9 \mathrm{hi}$ & $75.4 \mathrm{gh}$ \\
\hline & & & $42.19+84.38$ & $3.8 \mathrm{fgh}$ & $6.4 \mathrm{efg}$ & $80.6 \mathrm{de}$ & $79.4 \mathrm{def}$ \\
\hline & & & $56.25+112.50$ & $3.2 \mathrm{ij}$ & $5.2 \mathrm{ghi}$ & $83.8 \mathrm{bc}$ & $83.0 \mathrm{bc}$ \\
\hline \multirow[t]{3}{*}{ Merivon } & Pyraclostrobin+Fluxapyroxad & Strobilurin+SDHI & $57.24+57.24$ & $4.1 \mathrm{efg}$ & 6.4 efg & $79.1 \mathrm{ef}$ & 79.4 def \\
\hline & & & $71.55+71.55$ & $3.2 \mathrm{ij}$ & $5.2 \mathrm{ghi}$ & $83.9 \mathrm{bc}$ & $83.3 \mathrm{~b}$ \\
\hline & & & $95.40+95.40$ & $2.9 \mathrm{j}$ & $4.3 \mathrm{i}$ & $85.3 \mathrm{ab}$ & $86.1 \mathrm{a}$ \\
\hline
\end{tabular}

\footnotetext{
${ }^{\mathrm{y}}$ Control efficacies of six fungicides against asparagus stem blight was evaluated on the 3-year-old plants of the asparagus hybrid cv. Grande F1.

${ }^{z}$ Mean \pm SEM (standard error of the mean); values in the same column indicate significant difference by Duncan's new multiple-range test $(P \leq 0.05)$.
} 
for sensitivity shifts to pyraclostrobin, tebuconazole, and fluazinam treatments in the future is essential to ensure these fungicides will continue to manage asparagus stem blight effectively.

The AOX pathway may result in inaccuracies in vitro sensitivity evaluations of some fungi to the QoIs. Consequently, SHAM, an inhibitor of the pathway, is often added to fungicide sensitivity assays to inhibit AOX (Duan et al. 2012; Xu et al. 2012). However, there are numerous reports of SHAM affecting the sensitivity of fungi to QoI fungicides in different ways. In some reports, SHAM at $100 \mu \mathrm{g} / \mathrm{ml}$ decreased $\mathrm{EC}_{50}$ values of $S$. sclerotiorum to QoI fungicides (Duan et al. 2012). In others, the $\mathrm{EC}_{50}$ values of Fusicladium effusum and Microdochium majus to azoxystrobin were higher in the presence of SHAM than that of azoxystrobin alone (Seyran et al. 2010; Walker et al. 2009). In our study, we detected similar $\mathrm{EC}_{50}$ values for pyraclostrobin with and without SHAM at $20 \mu \mathrm{g} / \mathrm{ml}$. Therefore, we suggest that SHAM is not needed to determine the sensitivity of $P$. asparagi to pyraclostrobin on mycelial growth inhibition assay.

Differences in efficacy among the six fungicides occurred in both field and greenhouse trials. In the greenhouse studies, Merivon, Frown-cide, Cabrio, and Nativo provided the higher preventive and curative efficacies against $P$. asparagi than all other fungicides tested. The lowest preventive and curative efficacies were observed with Dithane M-45. Overall, the preventive efficacies of fungicides tested were higher than their respective curative efficacies under the same conditions in the greenhouse $(P<0.05)$, indicating that these fungicides should be applied as preventive protectants before infections occur, rather than as curative fungicide after infection to control P. asparagi (Smith et al. 2008). Indeed, our results are similar to other studies that reported DMI fungicides, QoI fungicides, and fluazinam should be applied as preventive measures against $S$. sclerotiorum (Di et al. 2016; Li et al. 2015; Liang et al. 2015a). In the field trials, the rainfall $(170.1 \mathrm{~mm})$ from 28 April to 25 May 2018 far exceeded that (49.8 mm) from 5 September to 2 October 2017 in Zhuangbian Town. Accordingly, the disease incidence of the control group in 2018 was higher than that in 2017 . Humid and rainy weather conditions are favorable for asparagus stem blight development (Davis 2001). Consistent with the results in the greenhouse, the lowest efficacy occurred in Dithane M-45, although this fungicide still reduced disease compared to the nontreated controls in the field. Among six fungicides, Frown-cide, Merivon, Nativo, and Cabrio reduced asparagus stem blight the most; therefore, these fungicides could be alternative fungicides to manage $P$. asparagi that is resistant to thiophanate methyl, carbendazol, and mancozeb. At present, although the resistance of $P$. asparagi to pyraclostrobin, fluazinam, and tebuconazole remains unreported, DMIs and QoIs are considered to be a medium-to-high risk for developing resistance. Accordingly, limiting the number of sprays, rotating with fungicides of different modes of action, and timely monitoring of susceptibility are essential for avoiding or delaying the development of resistance and maintaining efficacy.

Asparagus stem blight continues to spread as areas of cultivation expand to other countries (Davis 2001; Elena 2006; Zaw et al. 2017). It is now a devastating disease globally (Zhang et al. 2017). Although responsible application of highly effective fungicides has an important role in controlling stem blight, management of the disease requires an integrated approach based on seed treatment, water control, sound nutrition, host-plant resistance, and biological control. New cultural strategies will enable producers to continue supplying the market with high-quality asparagus in the future.

\section{Literature Cited}

Ahmed, H. U., Chang, K. F., Hwang, S. F., Gossen, B. D., Strelkow, S. E., and Turnbull, G. D. 2014. Baseline sensitivity and population shifts of Didymella rabiei in chickpea to the QoI fungicide pyraclostrobin in Alberta, Canada. J. Plant Dis. Prot. 121:164-170.

Almehdar, H., Abdallah, H. M., Osman, A. M., and Abdel-Sattar, E. A. 2012. In vitro cytotoxic screening of selected Saudi medicinal plants. J. Nat. Med. 66: 406-412.
Amiri, A., Heath, S. M., and Peres, N. A. 2013. Phenotypic characterization of multifungicide resistance in Botrytis cinerea isolates from strawberry fields in Florida. Plant Dis. 97:393-401.

Banno, S., Yamashita, K., Fukumori, F., Okada, K., Uekusa, H., Takagaki, M., Kimura, M., and Fujimura, M. 2009. Characterization of QoI resistance in Botrytis cinerea and identification of two types of mitochondrial cytochrome $b$ gene. Plant Pathol. 58:120-129.

Bartlett, D. W., Clough, J. M., Godwin, J. R., Hall, A. A., Hamer, M., and ParrDobrzanski, B. 2002. The strobilurin fungicides. Pest Manag. Sci. 58:649-662.

Broders, K. D., Lipps, P. E., Paul, P. A., and Dorrance, A. E. 2007. Evaluation of Fusarium graminearum associated with corn and soybean seed and seedling disease in Ohio. Plant Dis. 91:1155-1160.

Chen, J. X., and Ye, Z. Y. 1999. Preliminary study on resistance of Phomopsis asparagi Sacc. to thiophanate-methyl. J. Nanjing Agric. Univ. 22:29-32 (in Chinese with English abstract).

Dai, Y. L., Gan, L., Ruan, H. C., Shi, N. N., Du, Y. X., Liao, L., Wei, Z. X., Teng, Z. Y., Chen, F. R., and Yang, X. J. 2018. Sensitivity of Cochliobolus heterostrophus to three demethylation inhibitor fungicides, propiconazole, diniconazole and prochloraz, and their efficacy against southern corn leaf blight in Fujian Province, China. Eur. J. Plant Pathol. 152:447-459.

Davis, R. D. 2001. Asparagus stem blight recorded in Australia. Australas. Plant Pathol. 30:181-182.

Dehghan-Shahreza, F., Beladi-Mousavi, S. S., and Rafieian-Kopaei, M. 2016. Medicinal plants and diabetic kidney disease: An updated review on the recent findings. Immunopathol. Persa 2:1-6.

Di, Y. L., Zhu, Z. Q., Lu, X. M., and Zhu, F. X. 2016. Baseline sensitivity and efficacy of trifloxystrobin against Sclerotinia sclerotiorum. Crop Prot. 87: 31-36.

Dowley, L. J., and Sullivan, E. O. 1995. Activity of fluazinam against late blight of potatoes. Ir. J. Agric. Food Res. 34:33-37.

Duan, Y. B., Liu, S. M., Ge, C. Y., Feng, X. J., Chen, C. J., and Zhou, M. G. 2012. In vitro inhibition of Sclerotinia sclerotiorum by mixtures of azoxystrobin, SHAM, and thiram. Pestic. Biochem. Physiol. 103:101-107.

Elena, K. 2006. First report of Phomopsis asparagi causing stem blight of asparagus in Greece. Plant Pathol. 55:300.

Fan, K., Wang, J., Fu, L., Zhang, G. F., Wu, H. B., Feng, C. C., and Qu, J. L. 2019 Baseline sensitivity and control efficacy of pyraclostrobin against Botryosphaeria dothidea isolates in China. Plant Dis. 103:1458-1463.

FRAC (Fungicide Resistance Action Committee). 2014. FRAC Code List 2014: Fungicide sorted by mode of action. http://www.frac.info/publications/ downloads. Accessed 22 June 2014.

Guan, A., Liu, C., Huang, G., Li, H., Hao, S., Xu, Y., Xie, Y., and Li, Z. 2014 Synthesis and fungicidal activity of fluorine-containing chlorothalonil derivatives. J. Fluor. Chem. 160:82-87.

Hamamoto, H., Hasegawa, K., Lee, Y. J., Makizumi, Y., Akutsu, K., and Hibi, T. 2000. Tandem repeat of a transcriptional enhancer upstream of the sterol $14 \alpha-$ demethylase gene (CYP51) in Penicillium digitatum. Appl. Environ. Microbiol. 66:3421-3426.

He, L. F., Li, X. X., Gao, Y. Y., Li, B. X., Mu, W., and Liu, F. 2018. Characterization and fungicide sensitivity of Colletotrichum spp. from different hosts in Shandong, China. Plant Dis. https://doi.org/10.1094/PDIS04-18-0597-RE

Ivic, D. 2010. Curative and eradicative effects of fungicides. Pages 1-22 in: Fungicides. C. Odile, ed. ISBN: 978-953-307-266-1. InTech, Rijeka, Croatia.

Kaneko, I., and Ishii, H. 2009. Effect of azoxystrobin on activities of antioxidant enzymes and alternative oxidase in wheat head blight pathogens Fusarium graminearum and Microdochium nivale. J. Gen. Plant Pathol. 75:388-398.

Lemay, A. V., Bailey, J. E., and Shew, B. B. 2002. Resistance of peanut to Sclerotinia blight and the effect of acibenzolar-s-methyl and fluazinam on disease incidence. Plant Dis. 86:1315-1317.

Li, J. L., Liu, X. Y., Di, Y. L., Liang, H. J., and Zhu, F. X. 2015. Baseline sensitivity and control efficacy of DMI fungicide epoxiconazole against Sclerotinia sclerotiorum. Eur. J. Plant Pathol. 141:237-246.

Li, X., Sun, C., and Zhang, T. 2016. Study on the effect of asparagus extracts on promoting metabolism of the body. Acta Univ. Cibiniensis Ser. E. 20:121-130.

Liang, H. J., Di, Y. L., Li, J. L., You, H., and Zhu, F. X. 2015a. Baseline sensitivity and control efficacy of fluazinam against Sclerotinia sclerotiorum. Eur. J. Plant Pathol. 142:691-699.

Liang, H. J., Di, Y. L., Li, J. L., You, H., and Zhu, F. X. 2015b. Baseline sensitivity of pyraclostrobin and toxicity of SHAM to Sclerotinia sclerotiorum. Plant Dis. 99:267-273.

Liang, R., Li, X., Yuan, W., Jin, S., Hou, S., Wang, M., and Wang, H. 2018. Antifungal activity of nanochitin whisker against crown rot diseases of wheat. J. Agric. Food Chem. doi:

Liu, Y., Sang, H. X., Wang, J. S., Yu, Y. H., Song, C. Y., Ma, X. H., and Yu, S. Z 2013. Study on the optimum application period of trifloxystrobin tebuconazole 75\% WG against main rice diseases in coastal region. World Pestic. 35:59-61 (in Chinese with English abstract).

Liu, Y. C., and Zhang, H. L. 2017. The mixture of fenbuconazole and fluazinam against strawberry powdery mildew and strawberry gray mould. Agrochemicals 56:374-376.

McDonald, J. H. 2009. Handbook of Biological Statistics, 2nd Ed. Sparky House Publishing, Baltimore. 
Meng, F. 2013. Study on the biological characteristics and resistance of the asparagus stem blight [dissertation]. Jiangxi Agricultural University, Nanchang, China.

Meng, F., Yang, Y. Q., Lan, B., and Li, X. M. 2013. Difference of fungicide resistance of asparagus stem blight fungus from different geographic origins. J. Huazhong Agric. Univ. 32:61-65 (in Chinese with English abstract).

Milgate, A., Adorada, D., Orchard, B., and Pattemore, J. 2016. First report of resistance to DMI fungicides in Australian populations of the wheat pathogen, Zymoseptoria tritici. Plant Dis. 100:522.

Munkvold, G. P. 2009. Seed pathology progress in academia and industry. Annu. Rev. Phytopathol. 47:285-311.

Nielsen, B. J., and Schepers, H. T. A. M. 2014. Efficacy of fluazinam for control of potato late blight (Phytophthora infestans) in Danish field trials. Princeton University Press. 36:197-203.

Paul, P. A., Lipps, P. E., Hershman, D. E., McMullen, M. P., Draper, M. A., and Madden, L. V. 2007. A quantitative review of tebuconazole effect on fusarium head blight and deoxynivalenol content in wheat. Phytopathology 97:211-220.

Rusjan, D., and Mikulic-Petkovsek, M. 2017. Double maturation raisonnée: The impact of on-vine berry dehydration on the berry and wine composition of Merlot (Vitis vinifera L.). J. Sci. Food Agr. 97:4835-4846.

Russell, P. 2002. Sensitivity Baselines in Fungicides Resistance Research and Management. Crop Life International, Brussels, Belgium. Pages 1-53.

Russell, P. E. 2004. Sensitivity baselines in fungicide resistance research and management. FRAC Monograph No. 3. FRAC, Brussels, Belgium. https:// www.frac.info/docs/default-source/publications/monographs/monograph-3.pdf. Accessed 6 January 2020.

Schonbaum, G. R., Bonner, W. D., Jr., Storey, B. T., and Bahr, J. T. 1971. Specific inhibition of the cyanide-insensitive respiratory pathway in plant mitochondria by hydroxamic acids. Plant Physiol. 47:124-128.

Seyran, M., Brennenman, T. B., and Stevenson, K. L. 2010. In vitro toxicity of alternative oxidase inhibitors salicylhydroxamic acid and propyl gallate on Fusicladium effusum. J. Pestic. Sci. 83:421-427.

Shi, N. N., Du, Y. X., Ruan, H. C., Gan, L., Yang, X. J., Dai, Y. L., and Chen, F. R. 2016. Baseline sensitivity of Botrytis cinerea to fluazinam and cross-resistance to different fungicides in Fujian province. Chin. J. Pestic. Sci. 18:535-539 (in Chinese with English abstract).

Shi, N. N., Ruan, H. C., Chen, F. R., Zhang, Y. L., Yang, X. J., Dai, Y. L., Gan, L., and Du, Y. X. 2017. Development and application of an allele-specific PCR assay for detecting T409C mutation of cyp51 gene linked with tebuconazole resistance in Villosiclava virens. Can. J. Plant Pathol. 39:318-324.

Smith, D. L., Garrison, M. C., Hollowell, J. E., Isleib, T. G., and Shewa, B. B. 2008. Evaluation of application timing and efficacy of the fungicides fluazinam and boscalid for control of Sclerotinia blight of peanut. Crop Prot. 27:823-833.

Sonoda, T., Uragami, A., and Kaji, K. 1997. Evaluation of Asparagus officinalis cultivars for resistance to stem blight by using a novel inoculation method. Hortic. Sci. 32:1085-1086.

Stammler, G., Taher, K., Koch, A., Haber, J., Liebmann, B., Bouagila, A., Yahyaoui, A., and Nasraoui, B. 2012. Sensitivity of Mycosphaerella graminicola isolates from Tunisia to epoxiconazole and pyraclostrobin. Crop Prot. 34:32-36.

Vitoratos, A. G. 2014. Mode of action and genetic analysis of resistance to fluazinam in Ustilago maydis. J. Phytopathol. 162:737-746.
Walker, A. S., Auclair, C., Gredt, M., and Leroux, P. 2009. First occurrence of resistance to strobilurin fungicides in Microdochium nivale and Microdochium majus from French naturally infected wheat grains. Pest Manag. Sci. 65: 906-915.

Wang, H. C., Zhou, M. G., Zhang, Y. J., Cheng, C. J., and Wang, J. X. 2007. Fungicidal activity of tebuconazole against Rhizoctonia solani and its application to rice. Chin. J. Pestic. Sci. 9:357-362 (in Chinese with English abstract).

Wang, W. P. 2015. A study of novel technology of controlling clubroot of Chinese cabbage and mode of action of fluazinam on Plasmodiophora brassicae. Dissertation, Shenyang Agricultural University.

Wang, Y., Duan, Y. B., and Zhou, M. G. 2016. Baseline sensitivity and efficacy of fluazinam in controlling Sclerotinia stem rot of rapeseed. Eur. J. Plant Pathol. 144:337-343.

Wise, K. A., Pasche, J. S., Gudmestad, N. C., Dugan, F. M., and Chen, W. 2008 Baseline sensitivity of Ascochyta rabiei to azoxystrobin, pyraclostrobin, and boscalid. Plant Dis. 92:295-300.

Xu, T., Yao, F., Liang, W. S., Li, Y. H., Li, D. R., Wang, H., and Wang, Z. Y. 2012 Involvement of alternative oxidase in the regulation of growth, development, and resistance to oxidative stress of Sclerotinia sclerotiorum. J. Microbiol. 50:594-602.

Yang, L. J., and Bai, Y. L. 2012. Strobilurin fungicide-Pyraclostrobin. Mod. Agrochem. 11:46-56.

Yang, Y. Q., Lan, B., Jian, Y. L., Chang, D. D., Zhang, S. L., and Li, X. M. 2016. Infection process and pathogenic mechanism of Phomopsis asparagi, the asparagus stem blight pathogen. Phytoparasitica 44:11-18.

Yang, Y. Q., Li, X. Q., Meng, F., and Lan, B. 2012. Establishment of a resistanceidentification method on asparagus stem blight and evaluation of Asparagus officinalis germplasms. Acta Phytopathol. Sin. 42:649-654 (in Chinese with English abstract).

Yoshida, Y., and Aoyama, Y. 1987. Interaction of azole antifungal agents with cytochrome P-450 $14 \mathrm{DM}$ purified from Saccharomyces cerevisiae microsomes Biochem. Pharmacol. 36:229-235.

Yoshimura, M. A., Luo, Y., Ma, Z., and Michailides, T. J. 2004. Sensitivity of Monilinia fructicola from stone fruit to thiophanate-methyl, iprodione, and tebuconazole. Plant Dis. 88:373-378.

Zaw, M., Naing, T. A. A., and Matsumoto, M. 2017. First report of stem blight of asparagus caused by Phomopsis asparagi in Myanmar. New Dis. Rep. $35: 17$

Zhang, G. R., Pedersen, D. K., Phillips, D. V., and Bradley, C. A. 2012. Sensitivity of Cercospora sojina isolates to quinone outside inhibitor fungicides. Crop Prot. 40:63-68.

Zhang, Y. P., Chen, G. Y., Luo, S. C., Qu, H., Tang, Y. P., Xie, Q. X., and Zhou, J. S. 2012. Stress physiology and virulence characterization of Phomopsis asparagi (Sacc.) Bubak isolated from asparagus in Jiangxi province of China Agric. Sci. Technol. 13:1502-1508.

Zhang, Y. P., Qu, H. X., Zhao, P., Tang, Y. P., Zhou, J. X., Luo, S. C., Yin, Y. L., and Chen, G. Y. 2017. Generation and screening of T-DNA insertion mutants mediated by Agrobacterium tumefaciens in the garden asparagus stem blight pathogen Phomopsis asparagi. Curr. Microbiol. $74: 1270-1277$ 